\title{
Comunicação
}

[Communication]

\section{Campilobacteriose genital bovina em rebanhos leiteiros com problemas reprodutivos da microrregião de Varginha - Minas Gerais}

\author{
[Bovine genital campylobacteriosis in dairy herds with reproductive problems \\ of the microregion of Varginha, MG, Brazil] \\ A.P.R. Stynen ${ }^{1}$, A.O. Pellegrin ${ }^{2}$, C.B. Fóscolo ${ }^{1}$, J.F. Figueiredo ${ }^{1}$, \\ C. Canella Filho ${ }^{3}$, R.C. Leite ${ }^{1}$, A.P. Lage ${ }^{1 *}$ \\ ${ }^{1}$ Laboratório de Bacteriologia Aplicada, Núcleo de Pesquisa em Saúde Animal \\ Departamento de Med. Vet. Preventiva da Escola de Veterinária da UFMG \\ Caixa Postal 567 \\ 30123-970 - Belo Horizonte, MG \\ ${ }^{2}$ Embrapa Pantanal, Corumbá, MS \\ ${ }^{3}$ Veterinário autônomo, Varginha, MG
}

Recebido para publicação em 28 de junho de 2001.

Recebido para publicação, após modificações, em 20 de janeiro de 2003.

*Autor para correspondência.

E-mail: alage@vet.ufmg.br

A campilobacteriose genital bovina é uma doença infecciosa de caráter venéreo, causada pelo Campylobacter fetus subespécie venerealis. A doença é responsável por prejuízos econômicos na bovinocultura por causar repetições de cio, morte embrionária e esterilidade enzoótica das fêmeas infectadas (Dekeyser, 1984).

A infecção geralmente resulta em doença subclínica que, muitas vezes, passa desapercebida na maioria das propriedades. Nas fêmeas, a doença caracteriza-se por infertilidade temporária como resultado de cervicite, endometrite e salpingite (Stoessel, 1982). Nos machos, a infecção limita-se à cavidade prepucial e não se observam anormalidades clínicas nos animais infectados (Dekeyser, 1984). Por serem portadores assintomáticos, os touros são caracterizados como os grandes responsáveis pela difusão da doença no rebanho (Garcia et al., 1983).

O diagnóstico da campilobacteriose genital bovina pode ser realizado pelas técnicas de imunofluorescência direta (Mellick et al., 1965; Winter et al., 1965; Figueiredo et al., 2002), de isolamento e identificação do agente (Leite, 1977; Stoessel, 1982), de aglutinação com muco cérvicovaginal (Eaglesome, Garcia, 1992), por testes imunoenzimáticos (Hum et al., 1991; Pellegrin, 2001) e por PCR (Stynen, 2000). Até as décadas de 1960 e 1970 dois métodos para detecção do agente em touros e de anticorpos específicos em fêmeas, respectivamente, eram bastante utilizados, a imunofluorescência direta e a muco-aglutinação.

D’Ápice (1956) foi o primeiro pesquisador que isolou o então denominado “Vibrio fetus” de um feto abortado, relatando a presença da "vibriose” no Brasil. A doença foi intensamente pesquisada até o final da década de 1970 quando foram realizados vários trabalhos de levantamento epidemiológico em rebanhos, utilizando inicialmente a técnica de muco-aglutinação em fêmeas. A partir da década de 1970, os estudos no país ficaram restritos a alguns levantamentos epidemiológicos em fêmeas ou touros, nos estados do Paraná, (Castro et al., 1971), Rio de Janeiro (Ramos, Guida, 1978; Jesus et al., 1999), São Paulo (Genovez et al., 1986), Minas Gerais (Lage et al., 1997) e Mato Grosso do Sul (Pellegrin et al., 


\section{Stynen et al.}

1999). A freqüência de fêmeas portadoras da campilobacteriose genital bovina situa-se entre 8\% (Castro et al., 1971) e 46,9\% (Jesus et al.,1999) e a de touros infectados de 16,7\% (Genovez et al.,1986) a 52,3\% (Pellegrin et al.,1999). Apesar da importância da região de Varginha na produção leitera do Estado, os dados epidemiológicos sobre a campilobacteriose genital bovina na região são escassos e provenientes, principalmente, de amostragem por demanda (Lage et al., 1997) ou de informações pessoais de proprietários ou técnicos que atuam no município e regiões circunvizinhas.

O objetivo deste trabalho foi avaliar a freqüência da campilobacteriose genital bovina em propriedades com problemas reprodutivos na microrregião de Varginha, Minas Gerais, pela técnica de imunofluorescência direta.

Entre os meses de janeiro e julho de 1998 foram estudadas nove propriedades situadas nos municípios de Carmo da Cachoeira, Três Corações, Três Pontas e Varginha da microrregião de Varginha, Minas Gerais. Os rebanhos, constituídos de animais leiteiros da raça Holandesa, apresentavam problemas reprodutivos, como elevadas taxas de retorno ao cio, abortos e aumento no intervalo entre os partos, comunicados pelos técnicos que assistiam às propriedades. Em duas propriedades adotava-se a monta natural e nas outras a inseminação artificial com repasse de touros após a segunda inseminação. Devido aos sinais clínicos apresentados pelos animais suspeitou-se de campilobacteriose genital bovina.

Amostras de muco cérvico-vaginal foram coletadas de 157 fêmeas em reprodução para diagnóstico pela técnica de imunofluorescência direta. A coleta de muco vaginal foi realizada segundo Fernandes e Gomes (1992). A reação de imunofluorescência direta foi realizada segundo metodologia descrita por Mellick et al. (1965), Winter et al. (1965) e Figueiredo et al. (2002).

Em todas as propriedades estudadas verificou-se a presença de $C$. fetus.

A freqüência (Tab.1) de animais positivos (25,5\%) assemelha-se à da doença observada nos estados do Rio de Janeiro e Minas Gerais por Jesus et al. (1999), que também amostraram rebanhos na mesma região do presente estudo.

Tabela 1. Freqüência de infecção por $C$. fetus em rebanhos leiteiros com problemas reprodutivos da Microrregião de Varginha, Minas Gerais, 1998

\begin{tabular}{lccc}
\hline Manejo reprodutivo & $\begin{array}{c}\text { Rebanhos } \\
\text { estudados }\end{array}$ & $\begin{array}{c}\text { Animais } \\
\text { testados }\end{array}$ & $\begin{array}{c}\text { Animais } \\
\text { infectados }\end{array}$ \\
\hline $\begin{array}{l}\text { Monta natural } \\
\text { Inseminação artificial }\end{array}$ & 2 & 26 & $7(26,9 \%)$ \\
com touro de repasse & 7 & 131 & $33(25,1 \%)$ \\
Total & 9 & 157 & $40(25,5 \%)$ \\
\hline
\end{tabular}

O número de animais positivos à imunofluorescência direta foi menor que o esperado para rebanhos com campilobacteriose genital bovina. Esse quadro se deve provavelmente à imunidade das vacas, adquirida após três a cinco cios, e à variação no número de organismos presentes no muco vaginal (Winter, 1982), que é maior durante o estro, o que diminui a sensibilidade da imunofluorescência direta para diagnóstico de fêmeas portadoras, uma vez que nem todas as fêmeas coletadas encontravam-se nestas condições.

Segundo Garcia e Brooks (1993), a transmissão do C. fetus subsp. venerealis de touros infectados para fêmeas pode variar de $50 \%$ a $100 \%$ e a presença do elevado número de rebanhos positivos para o microrganismo está relacionada principalmente com o inadequado manejo reprodutivo. A monta natural é considerada um dos principais fatores de risco para difusão da campilobacteriose genital bovina nos rebanhos, principalmente quando se utilizam touros sem controle sanitário para a doença (Stoessel, 1982).

A inseminação artificial (IA) é considerada a mais eficiente prática de prevenção da campilobacteriose genital bovina (Stoessel, 1982). Países que a adotaram em larga escala já não mais registram casos da 
doença. Entretanto, a utilização da inseminação artificial no Brasil é muito baixa, pois somente 4 a 5\% das fêmeas são inseminadas (Yassu, 1998).

Como as propriedades estudadas não adotavam a inseminação artificial de forma exclusiva, a presença do touro de repasse pode se constituir no maior fator de risco para a manutenção da doença.

O histórico de baixa fertilidade apresentado pelos animais foi atribuído à alta freqüência de fêmeas portadoras do C. fetus, demonstrando que a doença tem importância na eficiência reprodutiva do rebanho, mantendo-se entre as mais importantes causas de aborto recentemente diagnosticadas no país (Genovez, 1997).

Em razão das características epidemiológicas da campilobacteriose genital bovina, a partir de um único resultado positivo no rebanho ou lote, considera-se o rebanho ou lote como positivo e as medidas de controle devem ser adotadas em todo o rebanho ou lote (Stoessel, 1982; Lage, Leite, 2000).

Dentre as medidas de controle e erradicação da campilobacteriose genital bovina amplamente difundidas, a aquisição de touros com certificação negativa para a doença, que pode ser obtida pela realização periódica do diagnóstico, respeitando-se os critérios para maximizar a sensibilidade da técnica (Lage, Leite, 2000), e o repouso sexual das fêmeas portadoras, para que elas possam se recuperar da infecção, não são suficientes para o sucesso no controle da doença, devido à presença de fêmeas portadoras que podem manter a doença no rebanho (Dekeyser, 1984). Medidas mais eficazes como a vacinação de todas as fêmeas entre 30 e 45 dias antes da cobrição ou do início da estação de monta (Leite, 1977; Lage, Leite, 2000) e a implementação da inseminação artificial devem ser adotadas para se obter controle efetivo da doença (Stoessel, 1982; Dekeyser, 1984). Entretanto, mesmo a utilização de medidas comprovadamente eficientes na erradicação da doença, como a inseminação artificial, requer atenção e avaliação, pois, como demonstrado no presente estudo, a presença de touros de repasse contaminados pelo C. fetus subsp. venerealis mantém a doença no rebanho, anulando os benefícios da inseminação artificial no controle da campilobacteriose genital bovina.

O estudo mostra que a campilobacteriose genital bovina está presente na microrregião de Varginha, MG, mesmo em propriedades que adotam a IA com o repasse de touros.

Palavras-chave: campilobacteriose genital bovina, Campylobacter fetus, epidemiologia, inseminação artificial, monta natural

\begin{abstract}
The frequency of bovine genital campylobacteriosis (BGC) in 157 cows from nine herds from the microregion of Varginha - Minas Gerais - Brazil was evaluated. Farmers use either artificial insemination and natural breeding after two insemination procedures or natural breeding. The diagnosis of BGC was performed by the direct fluorescent antibody test (DFAT) using vaginal mucus. All studied herds showed C. fetus infected animals and, of 157 animals, 40 (25.5\%) were positive in DFAT: 7 (26.9\%) from herds with natural breeding and 33 (25.1\%) from herds with both artificial insemination and natural breeding after the second-to-third insemination. The high frequency of BGC found in this study shows that this disease is present among herds which have reproductive problems and the use of natural breeding after the second-to-third unsuccessful insemination could be a risk factor for the disease.
\end{abstract}

Keywords: bovine genital campylobacteriosis, Campylobacter fetus, epidemiology, artificial insemination

\title{
REFERÊNCIAS BIBLIOGRÁFICAS
}


CASTRO, A.F.P.; GIORGI, W.; AOKI, D. et al. Pesquisas de aglutininas anti-Vibrio fetus em mucos vaginais de rebanhos bovinos dos Estados de São Paulo, Minas Gerais e Paraná. Biológico, v.37, p.115118, 1971.

D'APICE, M. Ocorrência do aborto no Estado de São Paulo devido ao Vibrio fetus. Biológico, v.22, p.1518, 1956.

DEKEYSER, J. Bovine genital Campylobacteriosis. In: BUTZLER, J.P. Campylobacter infection in man and animal. Boca Raton: CRC Press, 1984. p.181-191.

EAGLESOME, M.D.; GARCIA, M.M. Microbial agents associated with bovine genital tract. Vet. Bull., v.62, p.743-775, 1992.

FERNADES, J.C.T.; GOMES, M.J.P. Campilobacteriose Bovina. In: CHARLES, T.P.; FURLONG, J. Doenças dos bovinos de leite adultos. Coronel Pacheco: EMBRAPA - CNPGL, 1992. 141-150p.

FIGUEIREDO, J.F.; PELLEGRIN, A.O.; FÓSCOLO, C.B. et al. Evaluation of direct immunofluorescent antibody test for the diagnosis of bovine genital Campylobacteriosis. Rev. Latinoam. Microbiol., v.44, p.118-123, 2002.

GARCIA, M.M.; RUCKERBAUER, G.M.; EAGLESOME, M.D. et al. Detection of Campylobacter fetus in artificial insemination bulls with a transport enrichment medium. Can. J. Comp. Med., v.47, p.336-340, 1983.

GARCIA, M.M; BROOKS, B.W. Campylobacter. In: GYLES, C.L.; THOEN, C.D. Pathogenesis of bacterial infections in animals. Iowa State University Press, 1993. p.262-272

GENOVEZ, M.E. Campilobacteriose genital bovina. In: SIMPÓSIO PFIZER SOBRE DOENÇAS INFECCIOSAS E VACINAS PARA BOVINOS, 2, CAXAMBU, 1997. Anais... Belo Horizonte, p.49-53.

GENOVEZ, M.E.; SCARCELLI, E.; PICONE, A.B.B. Avaliação de dois métodos de coleta de muco prepucial no diagnóstico da campilobacteriose genital no touro. Biológico, v.52, p.7-11, 1096.

HUM, S.; STEPHENS, L.R.; QUINN, C. Diagnosis by ELISA of bovine abortion due to Campylobacter fetus. Aust. Vet. J., v.8, p.272-275, 1991.

JESUS,V.L.T.; TRES, J.E.; JACOB, J.C.F. et al. Campilobacteriose genital bovina: ocorrência nos estados do Rio de Janeiro e Minas Gerais. Rev. Bras. Ciênc. Vet., v.6, p.133-136, 1999.

LAGE, A.P.; LEITE, R.C. Campilobacteriose genital bovina (Vibriose). Pec. Corte, v.100, p.50-54, 2000.

LAGE, A.P.; PELLEGRIN, A.O.; COSTA, G.M. et al. Campilobacteriose genital bovina: 21 anos de diagnóstico na Escola de Veterinária da UFMG. Rev. Bras. Reprod. Anim., v.21, p.164-166, 1997.

LEITE, R.C. Avaliação de alguns métodos de diagnóstico e análise custo/benefício do controle da campilobacteriose bovina. 1977. 38f. Dissertação (Mestrado em Medicina Veterinária). Escola de Veterinária, Universidade Federal de Minas Gerais, Belo Horizonte.

MELLICK, P.W.; WINTER, A.J.; McENTEE, K. Diagnosis of vibriosis in the bull by the use of the fluorescent antibody technique. Cornell Vet., v.55, p.280-294, 1965.

PELLEGRIN, A.O.; SERENO, J.R.B.; COSTA, G.M. et al. Prevalência da Campilobacteriose Genital Bovina em touros do Pantanal Mato-grossense. Comunicado Técnico Embrapa CPAP., v.23, p.1-13, 1999.

PELLEGRIN, A.O. Campilobacteriose genital bovina na sub-região da Nhecolândia - Pantanal Matogrossense e proposição de novas técnicas diagnósticas. 2001. 152f. Tese (Doutorado em Ciência Animal). Escola de Veterinária, Universidade Federal de Minas Gerais, Belo Horizonte.

RAMOS, A.; GUIDA, H.G. Aglutininas anti-Campylobacter fetus em mucos vaginais de bovinos do Estado do Rio de Janeiro. Rev. Bras. Reprod. Anim., v.2, p.715, 1978. 


\section{Campilobacteriose genital bovina...}

STOESSEL, F. Las enfermedades venereas: Trichomoniasis y vibriosis genital. Zaragoza: Acribia, 1982. 163p.

STYNEN, A.P.R. Deteç̧ão de Campylobacter fetus em lavados prepuciais de touros pela PCR. 2000. 36f. Dissertação (Mestrado em Medicina Veterinária). Escola de Veterinária, Universidade Federal de Minas Gerais, Belo Horizonte.

WINTER, A.J. Microbial immunity in the reproductive tract. J. Am. Vet. Med. Assoc., v.181, p.19691073, 1982.

WINTER, A.J.; BURDA, K.; DUNN, H.O. An evaluation of cultural techniques for the detection of Vibrio fetus in bovine semen. Cornell Vet., v.55, p.431-444, 1965. 